\title{
Life Cycle Inventory Analysis of Copper Production System in Chile
}

by Nobuhiko NARITA ${ }^{\mathrm{a}}$, Kohki ICHITSUBO ${ }^{\mathrm{b}}$,

Masayuki SAGISAKA ${ }^{\mathrm{c}}$, Tadao MORO $^{\mathrm{b}}$ and Atsushi INABA ${ }^{\mathrm{c}}$

a. Nippon Steel Technoresearch Corporation, Hon-machi 4-40, Naka-ku Yokohama, 231-0005, Japan

b. School of Science \& Engineering, Waseda University

c. National Institute of Advanced Industrial Science and Technology, 16-1 Onogawa, Tsukuba 305-8569, Japan

$\mathrm{CO}_{2}$ and $\mathrm{SO}_{2}$ emissions from the copper production system in Chile were quantitatively evaluated using Life Cycle Assessment (LCA) technique. In this study, inventories such as the fuel consumption of the unit processes were based on published papers. The following observations were made based on LCI analysis:

(1) $\mathrm{CO}_{2}$ emissions from the pyro- and hydro- metallurgical copper are about $0.88 \mathrm{~kg}$ and $2.36 \mathrm{~kg} / \mathrm{kg}-\mathrm{Cu}$, respectively. And, $1.9 \mathrm{kWh}$ and $3.0 \mathrm{kWh} / \mathrm{kg}$-Cu were consumed for the electricity, respectively. There is much variance in the $\mathrm{CO}_{2}$ emissions between pyro- and hydro- metallurgical copper, because sulfuric acid originated from the pyro-process is used for the leaching of hydro-process.

(2) $\mathrm{SO}_{2}$ emissions from the pyro- and hydro- metallurgical copper are about $0.19 \mathrm{~kg}$ and $0.23 \mathrm{~kg} / \mathrm{kg}-\mathrm{Cu}$, respectively. The desulfurization ratio on pyro-metallurgical copper production in Chile is estimated to be $81 \%$, which is lower than that of Japan.

(3) Pyro- and hydro-metallurgical coppers have a complementary relationship in the range of self-sufficient sulfuric acid.

The environmental burden to soil and water from the copper production system should be evaluated, because it is not covered in this study

KEY WORDS : Copper, Pyro-metallurgy, Hydro-metallurgy, Life Cycle Assessment, Sulfuric Acid, Chile

\section{1.はじめに}

著者らは, 前報 1 )で我が国における電気銅生産システムの $\mathrm{CO}_{2}$ 排出についてライフサイクルインベントリ (LCI) 分析を実施した。 その結果, 電気銅の $\mathrm{CO}_{2}$ 排出に関する過去の研究では, 銅生産シ ステムの環境負荷を，硫酸原料となる $\mathrm{SO}_{2}$ に配分する方法が異な るので, 電気銅の $\mathrm{CO}_{2}$ 排出は $\mathrm{SO}_{2}$ を含めた生産システムとして評 価することが重要であることなどを示した。しかしながら，我が 国には国内で生産される電気銅ばかりでなく, チリなどから輸入 された銅も供給されており，国内供給の約 2 割は輸入に依存して いる2)。一方，我が国に銅地金を輸出しているチリでは，乾式製 鍊による銅 (以下，乾式銅）生産に加え，湿式製鍊 (SX-EW：溶媒 抽出一電解採取法) による生産が急速に拡大している ${ }^{3)}$ 。しかし ながら，湿式製鍊で生産された銅 ( 以下, 湿式銅 ) 生産までの環 境負荷は, 大規模の生産が近年普及したばかりなので, 過去に LCI 分析された事例がない。

したがって，我が国に供給される銅の環境負荷を把握するため

* 2000 年 10 月 30 日受付 2001 年 3 月 6 日受理

1. (株) 日鐵テクノリサーチ研究開発部 技術主管 (現 （社) 産業環境管理協会)

2. 早稲田大学学生 理工学部

3. 正会員 工博 産業技術総合研究所ライフサイクルアセスメント研究セン ター

4. 正会員 早稲田大学教授 理工学部環境資源工学科

5. 工博 産業技術総合研究所ライフサイクルアセスメント研究センター

[ 著者連絡先 ] FAX 03-3832-2774 (産環協) E-mail : narita@jemai.or.jp

キーワード : 銅，乾式製錬，湿式製錬，ライフサイクルアセスメント，硫酸，チリ
には，乾式製鍊に加え湿式製鍊で生産された銅の環境負荷の評価 が欠かせない。そこで，本研究では代表的な銅の生産国であるチ リにおける，乾式および湿式製鍊による銅の環境負荷を明らかに することを目的として，エネルギー消費量と密接な関倸がある $\mathrm{CO}_{2}$ 排出および酸性雨の原因となる $\mathrm{SO}_{2}$ 排出を対象に, $\mathrm{LCI}$ 分析 を実施した。

\section{2. チリにおける銅の需給状況}

チリは，銅精鉱の供給国であるとともに，電気銅の最大の生産 国である。Fig.1 にはチリにおける鉱石（銅換算）および銅生産の 推移を示した ${ }^{3}$ 。硫化鉱を原料と寸る乾式銅の生産量は 1990 年以 降, 約 100 万 $\mathrm{t}$ で大きな増加がないのに対し, 主に酸化鉱を原料 と寸る湿式銅の生産は 1994 年以降急激に増加し, 1998 年には乾 式銅にほぼ匹敵する 110 万 $\mathrm{t}$ が生産された。銅の浸出を利用する 湿式製錬では，大量の硫酸が消費されるので，原料となる酸化鉱 に加え，硫酸の供給体制が整っていることが必要である。そのた め, チリでは乾式製鍊で併産される硫酸の生産量は 90 万 $\mathrm{t}(1990$ 年) から 290 万 $\mathrm{t}\left(1998\right.$ 年 ) 几と急激に増加している ${ }^{4)}$ (Fig.1)。こ の硫酸生産量の増加は, チリで 1994 年に制定された環境基本法に 基づいた $\mathrm{SO}_{2}$ 排出規制の強化に対応しており，チリの乾式銅製鍊 所における硫黄の硫酸への固定率 (以下, 脱硫率) は $32 \%(1990$ 年)から $81 \%$ (1998 年)へと大幅に向上したと推測される。(脱硫 率は, 鉱石中の硫黄量と回收硫酸中の硫黄量の比から算定した。) このように，チリにおける乾式銅，湿式銅生産は，それぞれ硫酸 の供給元，需要先の関係を有しており，相互補完的な役割を果た 


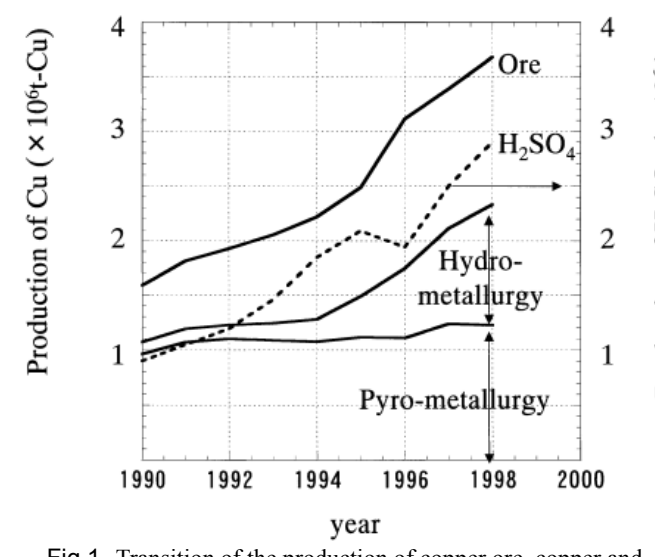

Fig.1 Transition of the production of copper ore, copper and sulfuric acid in Chile.

している。しかしながら，チリでは銅製錬ガスを原料とする硫酸 のみでは，湿式製錬を主体とする硫酸需要をまかなえないので, 我が国などから年間消費量の $12 \%$ に相当する 40 万 $\mathrm{t}$ の硫酸を輸 入している45)。ここで, チリでは原油脱硫などで生産される単体 硫黄を原料とする硫酸は，製錬ガスを原料とするそれの $5 \%$ に相 当する 15 万 $\mathrm{t}$ しか生産されていないので 4$)$, 輸入以外の硫酸は乾 式銅の生産工程で併産されていると考えることができる。なお, Fig.1 で示される鉱石生産量と銅生産量の差は, 海外に輸出されて いる銅精鉱に相当し, 1998 年には約 140 万 $\mathrm{t}-\mathrm{Cu}$ 相当の銅精鉱が輸 出されている。

一方, チリにおける銅の需要は小さいので, 生産された乾式・ 湿式銅の 90 \%がアジア,アメリカ地域を中心に輸出されている3)。

\section{3. 銅生産のインベントリ}

乾式および湿式銅生産までの $\mathrm{CO}_{2}, \mathrm{SO}_{2}$ 排出を定量的に評価す るため, 本研究では銅生産までの各素工程における環境負荷を計 量する「積み上げ法」による LCI 分析を実施した。

\section{$3 \cdot 1$ システム境界}

LCA の検討結果は, システム境界により大きく左右される。本 研究では, 最新のデータが揃っている 1998 年を対象に,「チリに おける鉱石等資材の採掘」から「チリにおける乾式・湿式銅生産 システム」までを検討対象とした。ここで, 銅生産システムとは, 銅製鍊で生産される銅に加え，併産される硫酸を含むシステム全 体を意味する。ただし，乾式製鍊で併産される金銀は，システム に含まれていない。

\section{$3 \cdot 2$ 乾式製錬}

チリにおける乾式銅生産に要するエネルギー消費原単位は，前 報 ${ }^{1)}$ で示した我が国の平均的な乾式製鍊のマテリアルフローおよ びエネルギー消費と同一であると仮定した。チリでは，近年反射 炉から自溶炉への転換が急速に進み, エネルギー消費原単位が削 減されており 6), またチリの代表的な乾式製錬所における電解精 製工程の電力消費原単位は我が国のそれとほぼ等しいので 7), 我 が国の生産システムと同一と仮定することは妥当と考えられる。 ここで，前報 ${ }^{1)}$ と同様に，銅製錬で消費される酸素全量は深冷分 離方式により自家製造されていると仮定した。Fig.2に示した乾式 製錬のマット工程，転炉工程で排出される $\mathrm{SO}_{2}$ は，前報 ${ }^{1)}$ と同様 に Table 1 に示した各中間製品の硫黄バランスから算定した。な お, 硫酸原料として用いられる $\mathrm{SO}_{2}$ は環境への排出ではないので, 硫酸生産量から推計される $\mathrm{SO}_{2}$ は環境への排出から差し引いた。 ここで, 硫酸原料となる $\mathrm{SO}_{2}$ を併産するマット工程および転炉工 程では, ISO-LCA ${ }^{8)}$ に従い，物理的関係を反映する重量基準の配 分手法を採用し，銅中間製品 (マット, 粗銅) と $\mathrm{SO}_{2}$ に原燃料を 配分した。なお, 電解精練工程で発生するアノードスライムから は金, 銀などの貴金属が回収されるが, その量は約 $1 \%$ と少なく,
[Cu production system in Chile]

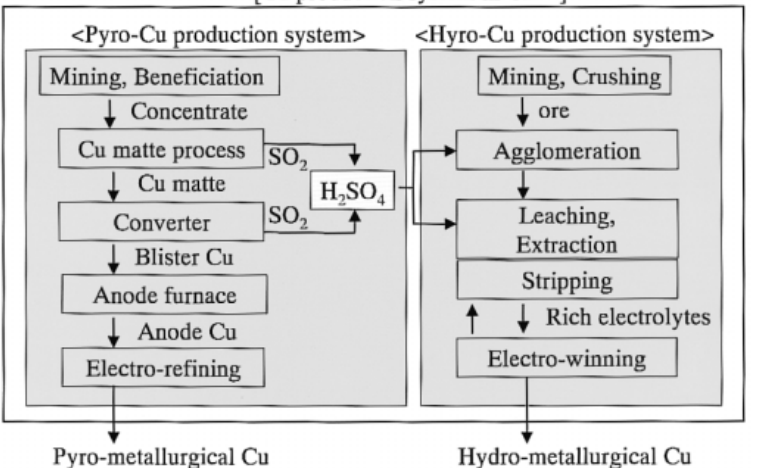

Fig.2 Material flow for producing pyro- and hydro-metallurgical copper in Chile.

Table 1 Constitution of primary ore and secondary products for pyro-metallurgical copper production

\begin{tabular}{c|c|c|c}
\hline & primary ore & \multicolumn{2}{|c}{ secondary products } \\
\hline Material & Cu concentrate & Cu matte & Blister Cu \\
\hline $\mathrm{Cu}$ & $32 \%$ & $60 \%$ & $98 \%$ \\
\hline $\mathrm{Fe}$ & $23 \%$ & $16 \%$ & \\
\hline $\mathrm{S}$ & $34 \%$ & $23 \%$ & \\
\hline $\mathrm{CaO}$ & $0 \%$ & & \\
\hline $\mathrm{SiO}_{2}$ & $7 \%$ & & \\
\hline $\mathrm{Al}_{2} \mathrm{O}_{3}$ & $3 \%$ & & \\
\hline
\end{tabular}

電気銅の環境負荷に及ぼす影響は小さいので，前報と同様に配分 の対象とはしなかった 1)。ただし, 電解精製工程で発生するスラ イムに価格基準で原燃料を配分した場合には, 電気銅の $\mathrm{CO}_{2}$ 排出 量は小さくなる可能性がある ${ }^{9)}$ 。

Fig.3 には，前報 ${ }^{1)}$ の分析に基づいたチリにおける乾式銅生産 までの主要な原然料のマスバランスおよびエネルギーバランスを 示す。この図の上段は硫酸の生産に, 下段は乾式銅の生産に対応 しており, 乾式銅 $1 \mathrm{~kg}$ を生産するとき, 硫酸 $2.4 \mathrm{~kg}$ が併産され る。ここで, 銅生産までに消費される電力は, 前報 1$)$ で示した我 が国と同様に, 自家発電が $30 \%$, 購入電力が $70 \%$ で構成されて いると仮定した。これは, 我が国と同様, チリにおいてもマット 工程, 転炉工程での廃熱が回収され, 自家発電に有効利用されて いると仮定したことを意味する。また, 購入電力には水力発電が 過半を占めるチリの電力構成 ${ }^{10)}$ に基づく環境負荷を適用した。

\section{$3 \cdot 3$ 湿式製錬}

湿式製錬による銅生産は, Fig.2 に示すように，採掘・粉砕，塊 状化, 浸出・抽出・逆抽出, 電解採取工程で構成され ${ }^{11)}$, 乾式製 錬における硫酸などの併産物は産出されない。湿式製鍊では，乾 式製錬で必要とされるマット工程などが省略されるが，浸出工程 などで乾式製鍊の併産物である硫酸を大量に消費する。以下に, 文献などに基づき作成した各工程における入出力データ（インベ ントリ）設定の考え方を示した。

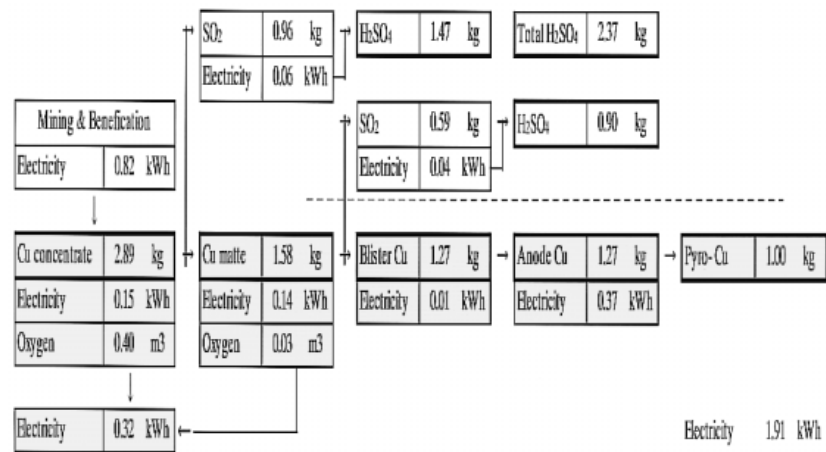

Fig.3 Material and energy balance for producing pyro-metallurgical $\mathrm{Cu}$ and $\mathrm{H}_{2} \mathrm{SO}_{4}$ in Chile. 
$3 \cdot 3 \cdot 1$ 鉱石採掘・粉砕湿式製錬では, 主に酸化鉱が用 いられるので，チリの代表的な酸化鉱鉱山での操業データ 12) か ら，採掘・粉砕には Fig.4のように鉱石 $1 \mathrm{~kg}$ 当たり $0.006 \mathrm{kWh}$ の 電力および $0.001 \mathrm{~kg}$ の軽油が消費されると仮定した。ここで, 乾 式製錬の原料として用いられる銅精鉱は, 浮選によって銅品位を 高めるために, $0.2 \mathrm{~mm}$ 前後の微細粒まで粉砕されるが, 湿式製錬 の原料となる酸化鉱は約 $10 \mathrm{~mm}$ までの粗粉砕で次工程に供される ので，この工程での電力消費は乾式製錬のそれより小さい。

$3 \cdot 3 \cdot 2$ 塊状化 (硫酸アグロメレーション) 塊状化は, 浸 出時の透水性の向上を図るとともに, 浸出反応の迅速化を目的に 実施されるが，塊鉱が浸出により崩壊する鉱石では採掘したまま の鉱石 $(-100 \mathrm{~mm})$ をそのまま浸出に供する場合もある ${ }^{13)}$ 。しかし ながら, 代表的な湿式製錬所の工程を調査した文献 ${ }^{14)}$ によれば, 硫酸を添加する塊状化 ( 硫酸アグロメレーション ) が多くの製錬 所で採用されているので, 本研究では文献 3 15) に示された原然料 消費に基づいて硫酸アグロメレーションが Fig.5 のように実施され ていると仮定した。なお，ここでは水 (約 $5 \%$ ) も添加されるが ${ }^{15}$ ), 図中では省略した。

$3 \cdot 3 \cdot 3$ 浸出・抽出 - 逆抽出塊状化された酸化鉱は, 主 に平坦地に堆積された後, 硫酸や水を散布することによって, 銅 イオンを含む浸出貴液が得られる ( 浸出工程 )。この浸出貴液は $\mathrm{pH}$ を調整し, 灯油で希釈された抽出剂と混合され, イオン交換反 応により銅が選択的に抽出される (抽出工程)。この高濃度の銅を 含む抽出液は, 高濃度の硫酸を用いて逆抽出され, 銅イオン濃度 が高められる (逆抽出工程)。ここで, 廃液処理や使用後の抽出剤 の再精製によって, Fig.6に示すように硫酸および抽出剤は循環利 用されるので，一つの単位工程として取り扱うことにした。

浸出から逆抽出を経て得られる電解液の生産までには, 文献 ${ }^{14)}$ に示されているチリの代表的な湿式製錬所の消費電力からFig.6の エネルギーを消費すると仮定した。ここで，中間製品となる電解 液は, 銅 $1 \mathrm{~kg}$ を含む電解液と定義した。この単位工程で, 浸出貴 液中の銅濃度は $2 \mathrm{~kg} / \mathrm{m}^{3}$ から, 電解採取に供される電解液の 50 $\mathrm{kg} / \mathrm{m}^{3}$ に高められるので ${ }^{3)}, 1 \mathrm{~kg}$ の銅を含んだ電解液を得るまで には膨大な量の硫酸が循環されていると推測できる。したがって, 本工程で消費される電力は, 硫酸および抽出剤の循環や再精製に 要するエネルギーに相当すると考えられる。なお, 抽出剤の消費

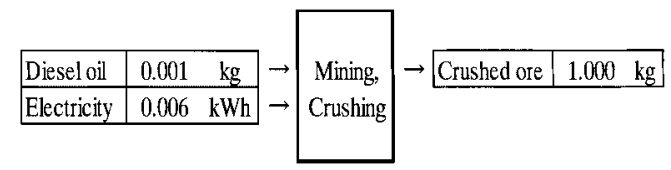

Fig.4 Inventory for the production of crushed ore for agglomerate.

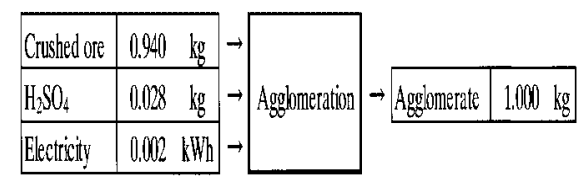

Fig.5 Inventory for the production of agglomerate

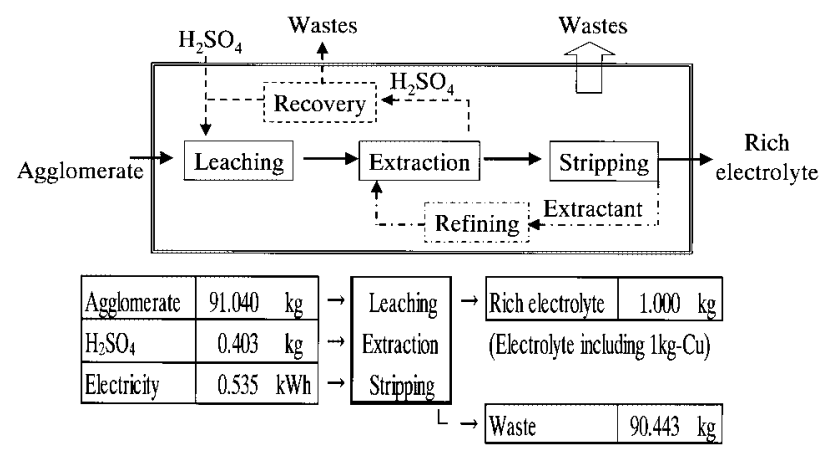

Fig.6 Inventory for the production of rich electrolyte.

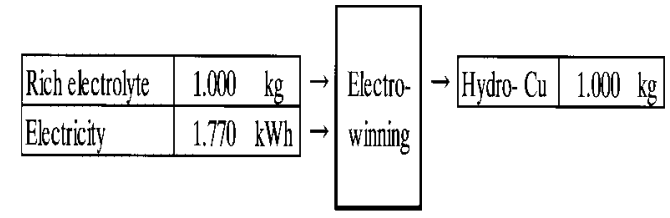

Fig.7 Inventory for the production of hydro-metallurgical $\mathrm{Cu}$.

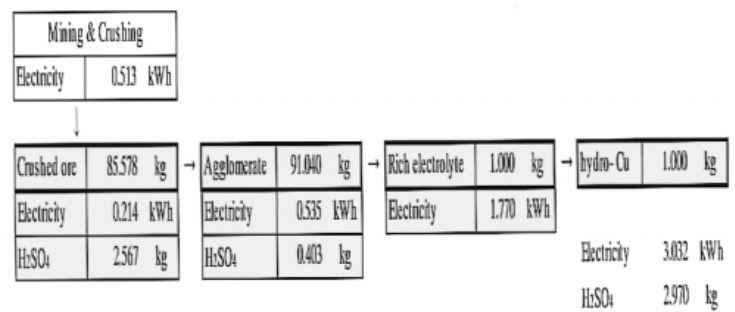

Fig.8 Material and energy balance for producing hydro-metallurgical Copper in Chile.

量は湿式銅 $1 \mathrm{~kg}$ 当たり $1.5 \mathrm{~g}$ と小さく ${ }^{16)}$, 基本的には循環利用さ れるので, その消費量は考慮しなかった。また, この単位工程で は酸化鉱を主体とする廃棄物が約 $90 \mathrm{~kg}$ 排出されるが, その処理 方式は明らかにされていない。今後, 廃棄物の処理工程を明らか にすることが課題である。

$3 \cdot 3 \cdot 4$ 電解採取 高濃度の銅を含む電解液からは電解採 取法により, 高純度の銅が生産される。Fig.7 に示した電解採取で の電力消費原単位は, 文献 ${ }^{14)}$ から $1.77 \mathrm{kWh} / \mathrm{kg}$ - 湿式銅と設定し たが, これは下記の電力消費量の推測 ${ }^{17)}$ からもほぼ妥当な值であ る。

$P(\mathrm{kWh} / \mathrm{kg})=Q_{0} \times V b / \varepsilon=0.844 \times 2 / 0.90=1.88 \mathrm{kWh} / \mathrm{kg}$-湿式銅 ここで, $Q_{0}$ : 銅電気分解の理論電気量, $V b$ : 浴電圧, $\varepsilon$ : 電流効率。

Fig.8には, 前項までに示した湿式銅生産までの主要な原燃料の マスバランスおよびエネルギーバランスを示す。湿式銅 $1 \mathrm{~kg}$ 生産 までには, $3.0 \mathrm{kWh}$ の電力および $3 \mathrm{~kg}$ の硫酸を消費し, 乾式銅の 約 $1.9 \mathrm{kWh}$ よりも電力消費が大きい。

採掘から製錬前処理工程までの電力消費量は, 乾式, 湿式製錬 でそれぞれ $0.82 \mathrm{kWh}, 0.51 \mathrm{kWh}$ であった。これは, 湿式製錬で は浮選を経ないので微粉砕が不要であり, 電力消費量が少ないこ とに対応している。一方, 湿式製鍊では電力を消費するイオン交 換による銅の濃縮, 電解採取工程を経るので, 乾式製錬よりも電 力消費量が大きい。

ここで，湿式製錬では，乾式製錬のように副生される蒸気はな いので, 電力は寸べて購入電力でまかなわれると仮定した。なお, 硫酸の一部は各国から輸入されているが，チリの輸入硫酸の 4 割 (1997 年) を占める我が国からす心゙て輸入されていると仮定した。 ここで輸入される硫酸は, 我が国の硫酸生産の約 5 割を占める銅 乾式製鍊で併産され ${ }^{18)}$, その $\mathrm{CO}_{2}$ 排出原単位は前報 ${ }^{1)}$ の分析結 果からチリへの輸送を含め $0.59 \mathrm{~kg}-\mathrm{CO}_{2} / \mathrm{kg}$ と仮定した。

また, 塊状化工程および浸出から逆抽出までの工程における硫 酸消費原単位 (3 kg/ kg- 湿式銅) から算定した硫酸消費量は, チリ における硫酸消費量の統計データ4）とほぼ一致した。

\section{$3 \cdot 4$ 分析手法}

Fig.3 で示したように, 乾式製錬ではマットおよび転炉の $2 つ 0$ 工程で硫酸の原料となる $\mathrm{SO}_{2}$ が併産されるので, これらの工程に おける原燃料消費の取り扱いにより乾式銅および硫酸の環境負荷 は大きく異なる。また, 湿式製錬では, 乾式製錬の併産物である $\mathrm{SO}_{2}$ を原料とした硫酸を大量に消費するので, 硫酸の環境負荷の 評価手法により, 湿式銅の環境負荷は異なると推測される。本研 究では乾式製錬で併産される硫酸原料となる $\mathrm{SO}_{2}$ を製品と考え, 乾式製錬に要する原燃料消費を銅中間製品 (マット, 粗銅 ) と $\mathrm{SO}_{2}$ に重量基準で配分した。一方, 湿式製鍊では銅以外に併産物はな いので，原燃料消費はすべて銅に配分される。

上記の仮定に基づき，資源環境技術総合研究所の開発している 


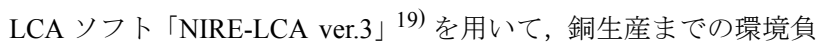
荷を試算した。

\section{4. 結果}

乾式および湿式製鍊で生産される銅の環境負荷を比較した結果 を Fig.9 に示す。乾式銅および湿式銅の $\mathrm{CO}_{2}$ 排出量は, おのおの $0.88 \mathrm{~kg}, 2.36 \mathrm{~kg} / \mathrm{kg}-\mathrm{Cu}$ と試算された。乾式銅の $\mathrm{CO}_{2}$ 排出のうち, 全体の約 4 割は電力に誘発された $\mathrm{CO}_{2}$ 排出であり, ほかは採掘・ 選鉱時に消費される軽油を主体とする燃料の燃焼時の $\mathrm{CO}_{2}$ 排出に 相当する。

一方，湿式製錬の電力消費量は乾式製錬より大きいので，全体 の $\mathrm{CO}_{2}$ 排出の 5 割以上が電力に誘発され, ほかは乾式銅と同様に 採掘時に消費された軽油の燃焼に相当している。また，輸入され た硫酸の $\mathrm{CO}_{2}$ 排出は， $0.21 \mathrm{~kg}$ で全体の約 $9 \%$ に相当する。

ここで，乾式製錬で消費される電力の $\mathrm{CO}_{2}$ 排出原単位は 0.35 $\mathrm{kg}-\mathrm{CO}_{2} / \mathrm{kWh}$ で，湿式製錬で消費されるチリの公共電力の原単位

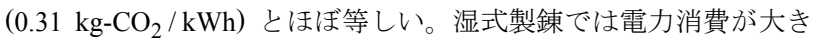
く, 乾式製錬で併産される硫酸を消費する場合には, 乾式銅の 2.5 倍以上の $\mathrm{CO}_{2}$ が排出されることになる。

乾式銅および湿式銅生産までの $\mathrm{SO}_{2}$ 排出量は, おのおの $0.19 \mathrm{~kg}$, $0.23 \mathrm{~kg}$ であり, 大きな差異はない。湿式製錬で発生する硫酸ミス 卜は最終的には水圈, 土袞に排出されると考えられるので, 大気 圏へ $\mathrm{SO}_{2}$ は排出されないが, 乾式製錬で排出される $\mathrm{SO}_{2}$ 排出が硫 酸に配分されるので, 湿式銅も $\mathrm{SO}_{2}$ を排出する。

\section{5. 考察}

\section{$5 \cdot 1$ 電力消費原単位の妥当性}

湿式銅の生産までの $\mathrm{CO}_{2}$ 排出のうち, 電力に誘発されている割 合が 5 割以上と大きい。しかし, 湿式製錬での環境負荷について は，過去に分析された事例がない。そこで，本研究で設定した湿 式製鍊の電力消費原単位の妥当性を検討した。

チリの電力消費量の内訳は, OECD の発行している統計資料 ${ }^{10)}$ により把握でき, 1997 年のチリの全電力消費量 $31 \mathrm{TWh} の$ 約 3 割 を占める $9 \mathrm{TWh}$ が, 非鉄製錬業で消費されていることが示されて いる。チリでは銅製鍊で併産される金，銀を初め，銅精鉱の併産 物としてモリブデンが製鍊されている ${ }^{20)}$ が, 圧倒的に銅製鍊の占 める割合が高い21）。したがって，前章 4 . までに得られた電力消 費原単位と乾式・湿式銅生産量から銅生産までの電力消費量を推 測することにより，設定された電力消費原単位の妥当性を検討す ることができる。ここでは, 1990 年以降の非鉄製錬業の電力消費 量の推移と, 本研究で得られた乾式・湿式製鍊の電力消費原単位 から推測される電力消費量の関係を検討した。

その結果，Fig.10に示すように，チリ国内での乾式・湿式製錬 の電力消費量と，輸出される銅精鉱の粉砕・浮選用電力消費量の 総計は，チリでの非鉄製錬業の消費電力量増大の傾向をほぼ反映

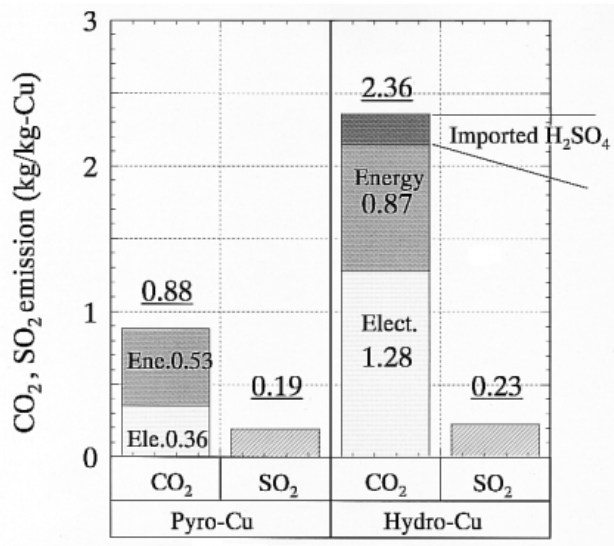

Fig.9 Comparison of $\mathrm{CO}_{2}, \mathrm{SO}_{2}$ emissions between pyro- and hydro-metallurgical copper.

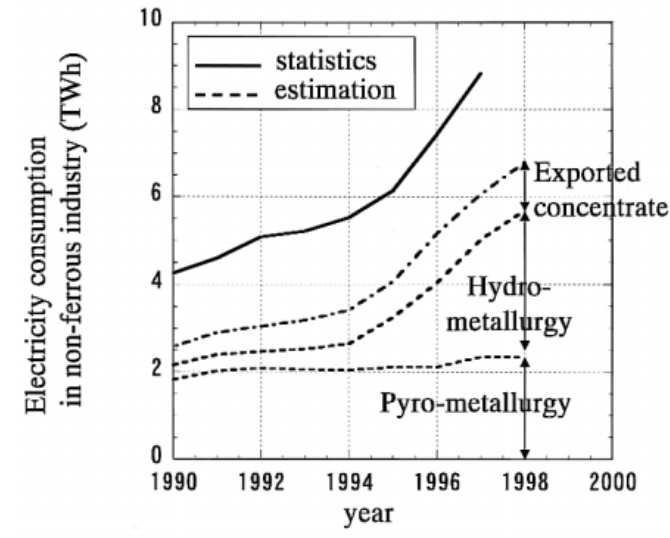

Fig.10 Comparison of electricity consumption in statistics with estimated consumption of this study.

していることが示された。Fig.10 で，統計值と推測值の差異は金， 銀, モリブデンなどの非鉄金属の採掘，製錬に要する電力に相当 し，金，銀およびモリブデンの生産量はほぼ一定であるので ${ }^{21)}$, 本研究で仮定した電力消費量が妥当であると考えられる。

\section{$5 \cdot 2$ 銅の環境負荷の変動因子}

$5 \cdot 2 \cdot 1$ 配分手法の影響本研究では, 併産物のある工程 での原燃料を，もっとも一般的な重量基準で配分した。しかし， 併産される $\mathrm{SO}_{2}$ を原料とする硫酸は「副生品」であるので, 原燃 料を配分せず，乾式銅のみに環境負荷を配分する手法も適用でき る。そこで, 以下には配分手法による $\mathrm{CO}_{2}$ 排出量の差異について 検討した。

その結果，硫酸に原燃料消費が配分されない場合の乾式銅の $\mathrm{CO}_{2}$ 排出量はFig.11に示すように, $1.68 \mathrm{~kg} / \mathrm{kg}-\mathrm{Cu}$ と試算された。 ここで, 乾式銅の $\mathrm{CO}_{2}$ 排出量は, 重量基準の配分法では硫酸に配 分された原燃料消費を, 乾式銅の $\mathrm{CO}_{2}$ 排出量に加算することを意 味するので，硫酸に原燃料消費を配分した場合の乾式銅の $\mathrm{CO}_{2}$ 排 出である $0.88 \mathrm{~kg}$ より大きく, $1.68 \mathrm{~kg}$ と評価される。これは, 単 位重量 $(1 \mathrm{~kg})$ の乾式銅と付随した硫酸 $(2.37 \mathrm{~kg}$ : Fig.3 参照 $)$ を生 産する「乾式銅生産システム」全体の $\mathrm{CO}_{2}$ 排出量に相当する。一 方, 湿式製鍊で消費される硫酸の $\mathrm{CO}_{2}$ 排出は, 既に乾式銅に加算 されているので, 「0」である。したがって, 湿式銅の $\mathrm{CO}_{2}$ 排出量 は, Fig.9の $2.36 \mathrm{~kg}$ から硫酸の $\mathrm{CO}_{2}$ 排出相当分が減ぜられ, 1.27 $\mathrm{kg} / \mathrm{kg}-\mathrm{Cu}$ と評価される。

このように, 乾式, 湿式銅の $\mathrm{CO}_{2}$ 排出量は, 硫酸に原燃料消費 を配分する手法によって異なる。しかし, 現在では, 湿式銅の品 質は乾式銅のそれに劣らず，区別されないので，乾式銅，湿式銅 それぞれの $\mathrm{CO}_{2}$ 排出量を評価するよりも，「銅」生産システム全 体の環境負荷を評価することが適切である。ここで「銅」は，乾 式銅と湿式銅の生産量を考慮した平均的な銅を示す。1998年には,

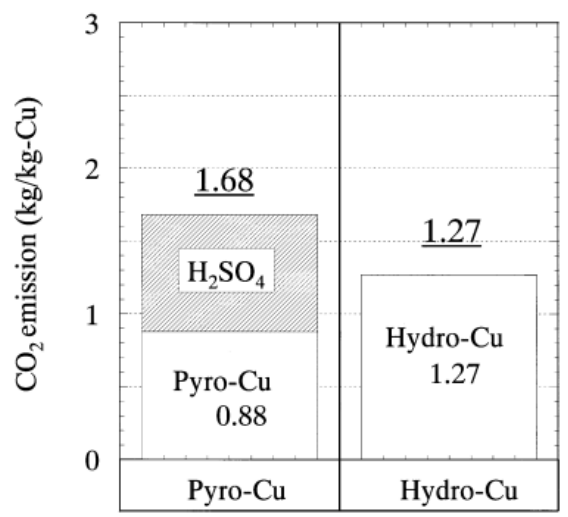

Fig.11 Effects of the allocation on $\mathrm{CO}_{2}$ emissions between pyro- and hydro-metallurgical coppers. 
乾式，湿式銅の生産比は，それぞれ $52.5 \%, 47.5 \%$ であるので, 硫酸に原燃料消費が配分されない場合，「銅」の $\mathrm{CO}_{2}$ 排出量は， $1.48 \mathrm{~kg}(=1.68 \times 0.525+1.27 \times 0.475)$ である。一方，硫酸に原燃 料を配分した場合 (Fig.9) には，チリ国内で $1.48 \mathrm{~kg}\{=0.88 \times 0.525$ $+(2.36-0.21) \times 0.475\}$ の $\mathrm{CO}_{2}$ が排出され, 配分手法によらず, 「銅」の $\mathrm{CO}_{2}$ 排出量は一定である。

$5 \cdot 2 \cdot 2$ 湿式製錬増加による環境負荷の変化 チリでは, $\mathrm{SO}_{2}$ 排出規制の強化に伴い，製鍊ガス中の $\mathrm{SO}_{2}$ を硫酸として固定 化し, 生産された硫酸は湿式製鍊で消費されてきた。したがって, ほぼ硫酸需給はバランスし, 硫酸生産量が湿式銅の生産量を支配 してきた。1990 年以降, 脱硫率が高まった結果, 銅生産に占める 湿式銅の生産比は増大し, 1998 年にはそれらの生産量はほぼ等し くなっている。

そこで, 1990 年以降の「銅」生産 $1 \mathrm{~kg}$ 当たりの $\mathrm{CO}_{2}, \mathrm{SO}_{2}$ 排出 の変化を, 銅生産に占める湿式銅の生産比を变数にして試算した。 ここで，過去の銅生産の原燃料消費原単位は本研究で用いた条件 と等しく, 脱硫率 (すなわち, 硫酸生産量) のみが変化したと仮 定した。

その結果，Fig.12 に示すように, 銅」 $1 \mathrm{~kg}$ 当たりの $\mathrm{SO}_{2}$ 排出 量は脱硫率が高まったので, 湿式銅生産比とともに急激に低下し たと試算された。ここで, 湿式銅生産比が 0.23 における $\mathrm{SO}_{2}$ 排出 量 ( 約 $1 \mathrm{~kg} / \mathrm{kg}-\mathrm{Cu}$ ) は, 脱硫率 $32 \%$ (1990 年) に相当している。 また, 湿式銅生産比が 0.5 では, 鉱石中に含まれる硫黄のすべて が硫酸に固定される。したがって, 湿式銅生産比が 0.5 以上では 湿式製錬に必要な硫酸をチリの銅乾式製錬からは供給できないの で, 湿式製錬拡大のためには硫酸を外部から調達する必要がある。 これは, 湿式銅生産比が 0.5 未満では乾式製錬と湿式製鍊は相互 補完の関係を有していたことを意味している。

また,「銅」生産システムにおける $\mathrm{CO}_{2}$ 排出は湿式銅生産比と ともに徐々に削減されたと試算された (Fig.12)。この理由は, 次の ように考えられる。脱硫率とともに硫酸生産量が高まると, 湿式 銅の生産比が高まるので, 電力消費量は増大し, 電力誘発の $\mathrm{CO}_{2}$ 排出量は増える。しかし, 乾式製錬で消費されていたエネルギー に誘発される $\mathrm{CO}_{2}$ が削減されるので, 「銅」生産システム全体と しての $\mathrm{CO}_{2}$ 排出量は削減される。

しかし，湿式銅生産比が 0.5 以上では，銅乾式製錬から硫酸が 供給されないので, 輸入などによって新たに供給される硫酸の $\mathrm{CO}_{2}$ 排出により,「銅」生産システム全体の $\mathrm{CO}_{2}$ 排出量は変化す る。たとえば，仮想的にチリでの乾式製錬と同様なシステムで生 産される硫酸に $\mathrm{CO}_{2}$ 排出が配分された場合には, Fig.12 中の (a)の ように,「銅」の $\mathrm{CO}_{2}$ 排出は急激に増大寸る。しかし, 外部調達 される硫酸に $\mathrm{CO}_{2}$ 排出が配分されない場合には (b) のように, 湿 式銅の $\mathrm{CO}_{2}$ 排出量は $1.27 \mathrm{~kg}$ である。なお, (c) は本研究で仮定し た「我が国から外部調達された硫酸」がある場合の $\mathrm{CO}_{2}$ 排出に相 当し, 輸入硫酸に誘発される $\mathrm{CO}_{2}$ 排出が加算されるので, 湿式銅 の $\mathrm{CO}_{2}$ 排出量は $2.36 \mathrm{~kg}$ と試算される。

このように, 1990 年以降のチリの「銅」生産システム全体の $\mathrm{CO}_{2}$ 排出原単位が低下してきたのは, 乾式製鍊で消費されていた エネルギーに誘発される $\mathrm{CO}_{2}$ 排出が削減されたためである。しか し, 湿式銅生産比が 0.5 以上では硫酸を銅製鍊から供給できなく なるので, 外部調達される硫酸に依存した湿式銅生産比の増大は, 硫酸に原燃料が配分された場合 Fig.12中の (a)のように「銅」 $1 \mathrm{~kg}$ 当たりの $\mathrm{CO}_{2}$ 排出量を急激に増加させることとなる。

一方, チリの電力供給の主力であった水力発電量は Fig.13 に示 すように, 1992 年以降ほぼ一定で, 近年は火力発電量が急激に増 大している 10)。その結果, Fig.13 中に示したように, チリの電源 構成に占める水力発電比率は, $75 \%$ (1992 年) から $55 \%$ (1998 年) へと低下を続けているので, 今後湿式製錬の拡大に伴う電力は火 力発電によってまかなわれると考えられる。これは, 電力の $\mathrm{CO}_{2}$ 排出原単位の増加を導くので, 電力を多消費する湿式銅の $\mathrm{CO}_{2}$ 排

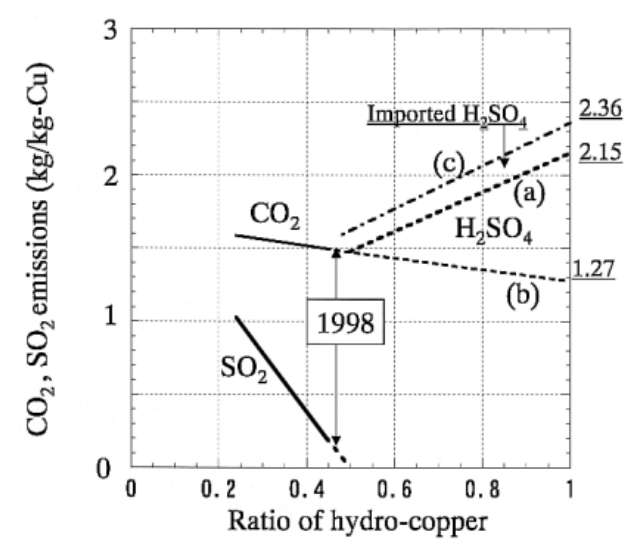

Fig.12 Relationship between $\mathrm{CO}_{2}, \mathrm{SO}_{2}$ emissions and ratio of hydro-metallurgical copper.

出量が一層増大寸ることを意味し,「銅」生産システムの $\mathrm{CO}_{2}$ 排 出を増加させる。

\section{$5 \cdot 3$ 我が国に供給される銅の環境負荷}

我が国が輸入している銅 ( 陰極銅相当 ) は, 約 27 万 $\mathrm{t}$ であり (1998 年), そのうちチリからは約 $1 / 2$ に相当する 13 万 $\mathrm{t}$ が輸入さ れている ${ }^{2)}$ 。残りは, ザンビア, ペルーなどから輸入されている。 本節 $5 \cdot 3$ では, 我が国に輸入される銅の約 $1 / 2$ を占めるチリの 銅と我が国で生産される乾式銅の環境負荷を比較した。

重量基準の配分を用いて, 我が国で生産される乾式銅とチリか ら輸入される乾式・湿式銅の $\mathrm{CO}_{2}$ 排出原単位を比較した結果を Fig.14に示した。ここで, チリから輸入される銅には, 我が国一 の輸送に伴う公海上の $\mathrm{CO}_{2}$ 排出が付加されている。この図から, 我が国の乾式製鍊では, 硫黄を硫酸に固定する比率が $90 \%$ と高 いので, 乾式銅に配分される原燃料消費が小さいにもかかわらず, チリから輸入された乾式銅と $\mathrm{CO}_{2}$ 排出が等しい。これは, 我が国 とチリとの電源構成が異なり, 我が国の公共電力の $\mathrm{CO}_{2}$ 排出原単 位 $(0.42 \mathrm{~kg} / \mathrm{kWh})$ とチリのそれ $(0.31 \mathrm{~kg} / \mathrm{kWh})$ との差がチリの脱 硫率の低さ $(81 \%)$ を補った結果と考えられる。また, チリから輸 入される湿式銅の $\mathrm{CO}_{2}$ 排出原単位は, チリ国内での電力誘発 $\mathrm{CO}_{2}$ 排出が大きく, 我が国から輸入される硫酸の $\mathrm{CO}_{2}$ 排出も加算され るので, 乾式銅の 2.5 倍であった。一方, チリから輸入される乾 式・湿式銅の $\mathrm{SO}_{2}$ 排出は, Fig.9 に示したように, 約 $0.2 \mathrm{~kg} / \mathrm{kg}-\mathrm{Cu}$ である。我が国では, 鉱石中に含まれる硫黄の $99 \%$ は, 硫酸お よび石膏に固定され, 残りの約 $1 \%$ が環境中に放出されると報告 されているので ${ }^{22)}$, 乾式銅 $1 \mathrm{~kg}$ 当たりの $\mathrm{SO}_{2}$ 排出量は下記から $0.01 \mathrm{~kg}$ と推測される。

$\mathrm{SO}_{2}$ 排出 $(\mathrm{kg} / \mathrm{kg}-\mathrm{Cu})=$ 銅精鉱量 $\times$ 精鉱中の硫黄品位 $\times(1-$ 脱硫率 $)$ (Fig.3 参照) (Table1 参照)

$=2.89 \times 0.34 \times 0.01=0.01$

したがって, チリから輸入される乾式銅, 湿式銅生産までの $\mathrm{SO}_{2}$ 排出は我が国のそれの 20 倍にも相当する。

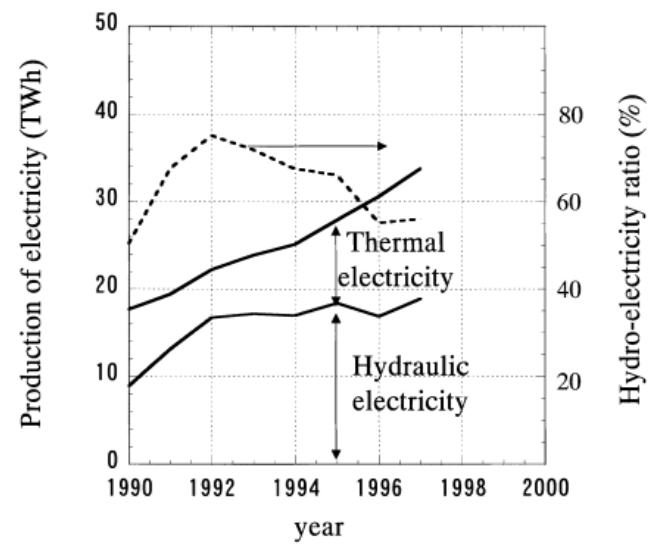

Fig.13 Transition of electricity supply in power system. 


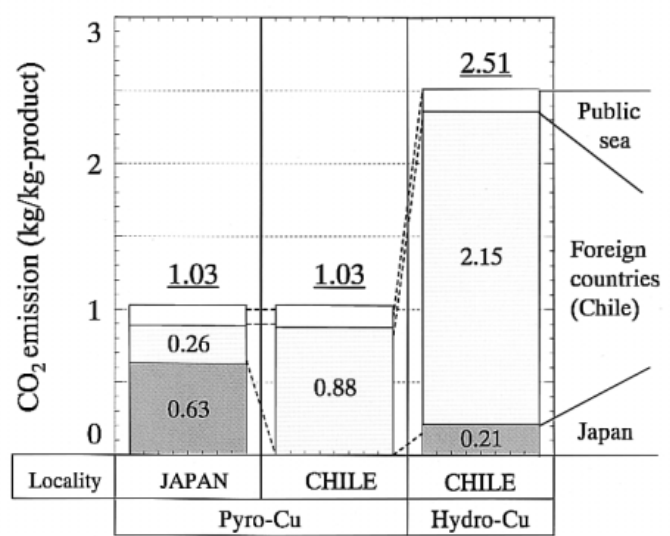

Fig.14 Comparison of $\mathrm{CO}_{2}$ emission between coppers supplied to Japan.

このように, チリから輸入される乾式銅の環境負荷は $\mathrm{CO}_{2}$ 排出 では我が国とほぼ同等であるが， $\mathrm{SO}_{2}$ 排出は大きいという特徵を 有する。

\section{$5 \cdot 4$ 本研究の課題}

本研究では, チリでの乾式製鍊における電力構成を, 我が国の 銅製鍊と同様の自家発電が導入され, 不足する電力はチリの公共電 力から供給されると仮定した。しかしながら，一部の製錬所では石 炭火力で発電された電力が採用されていると報告されている ${ }^{3) 23) 。 ~}$ 前述したように, 電力を多消費する湿式銅の $\mathrm{CO}_{2}$ 排出は電力に誘 発される割合が 5 割以上と高いので, 実際にチリの製錬所で用い られている発電システムにより $\mathrm{CO}_{2}$ 排出は異なる。今後, 製錬所 の実態に即した電力構成を明らかにし, 環境負荷の評価の精度を 上げることが本研究の今後の課題である。

また, 本研究では, 湿式銅生産比が 0.5 以上になった場合には, 銅製鍊ガスを原料とする硫酸が外部調達されると仮定し, $\mathrm{CO}_{2}$ 排 出量が急激に増加する可能性を示した。しかしながら, 単体硫黄 を原料とする硫酸を調達した場合には, その発熱反応のエネル ギーを回収することで, 製錬ガスを原料とする硫酸よりも $\mathrm{CO}_{2}$ 排 出面で有利となることが想定される。今後, チリにおける硫酸の 調達の在り方を提言していきたい。

チリにおける銅製錬に伴う大気圈への $\mathrm{SO}_{2}$ 排出は，環境規制の 強化とともに, $\mathrm{SO}_{2}$ を原料とした硫酸需要の高まりもあり, 着実 に減少している。しかしながら, 本研究では硫酸浸出後の残渣や 廃液処理の環境負荷については明らかにできなかった。残渣や廃 液は, 土壌や水圈への環境負荷の増大をもたらしている可能性が あるので ${ }^{24)}$, 今後残渣および廃液処理の実態についても把握し, 湿式製錬と乾式製錬の環境負荷を大気圈に加え，土壌，水圈の観 点から評価することも必要である。

\section{6. ま と め}

文献および統計データに基づいて，チリにおける乾式銅および 湿式銅生産システムの $\mathrm{CO}_{2}, \mathrm{SO}_{2}$ 排出を $\mathrm{LCI}$ 分析した。その結果,
乾式, 湿式銅の $\mathrm{CO}_{2}$ 排出量はそれぞれ $0.88 \mathrm{~kg}, 2.36 \mathrm{~kg} / \mathrm{kg}-\mathrm{Cu}$ と 試算された。それぞれの電力消費量は製鍊の手法が異なるので, $1.9 \mathrm{kWh}, 3.0 \mathrm{kWh}$ と異なる。乾式製錬で併産される $\mathrm{SO}_{2}$ を原料と する硫酸に原燃料を配分し，その硫酸が湿式製鍊で消費される場 合には, 乾式および湿式銅の $\mathrm{CO}_{2}$ 排出量には大きな差異が認めら れることになる。一方, 乾式, 湿式銅の $\mathrm{SO}_{2}$ 排出量はそれぞれ $0.19 \mathrm{~kg}, 0.23 \mathrm{~kg} / \mathrm{kg}-\mathrm{Cu}$ で, 大きな差異はなかった。チリの乾式 銅製錬における脱硫率は $81 \%$ で，我が国の $99 \%$ よりも低いの で，銅生産に伴う $\mathrm{SO}_{2}$ 排出が大きいと推測された。

また, 湿式銅生産比が 0.5 未満では, 湿式製錬で消費される硫 酸はチリの銅乾式製錬から供給されるので，乾式製鍊と湿式製錬 は相互補完の関係があり, 乾式製錬における脱硫率の向上により, 銅生産システムでの $\mathrm{CO}_{2}$ 排出原単位は $1.6 \mathrm{~kg}$ (1990 年) から $1.5 \mathrm{~kg}$ (1998 年) へと削減されてきた。しかし, チリの電力構成は近年水 力発電比率が下がっていることに加え, 湿式銅生産比が 0.5 以上 では硫酸を外部調達せざるを得ないので, 湿式銅の生産拡大は単 位重量当たりの銅の $\mathrm{CO}_{2}$ 排出を増大させる可能性があることを指 摘した。

本研究では, 湿式製鍊の残渣や廃液処理の環境負荷について明 確にできなかったので, 土猿や水圈への環境負荷の影響をも考慮 した LCI 分析を実施することが今後の課題である。

謝辞資源環境技術総合研究所 素材資源部 田中幹也室長 に，湿式製錬について議論いただき，感謝申し上げる。

\section{引用 文 献}

1）成田暢彦・匂坂正幸・稲葉 敦 : 資源と素材, Vol. 117 p. 49-55, (2001)

2) 通商産業大臣官房調查統計部編:平成10年資源統計年報,通商産業調查会, (1999)

3) 麻植邦敏 : SX-EW 法の現状と展望, 日本メタル経済研究所, (1999)

4）硫酸協会編：硫酸手帳, p. 35, 硫酸協会, (1999)

5）鶴田利行：化学経済 2000 年 3 月臨時増刊号，p. 128，化学工業日報社，(2000)

6) Codelco: http://www.codelcochile.com

7) Davenport, W.G. et al.: Proceedings of the copper 99 international conference, Vol. III, p. 3, The Minerals, Metals \& Materials Society, Pennsylvania, (1999)

8） JIS Q 14041：(1999.11.20 制定), 日本規格協会

9) Sugita, K. et al. : Proceedings of 4th International Conf. on Ecomaterials, p. 323, Gifu, (1999)

10) IEA : Energy Statistics of Non-OECD Countries 1996-1997, OECD, (1999)

11）田中幹也・六川暢了・小山和也：資源と環境, Vol. 4, p. 19, (1995)

12) Chapman P. F. and Roberts, F. : Metal Resources and Energy, p. 110, Butterworths, London, (1983)

13）高橋堅之・木村悦治・岩崎 峳：資源処理技術，Vol. 41, p. 94, (1994)

14) Jenkins, J. et al.: Proceedings of the copper 99 international conference, Vol. IV, p. 493, The Minerals, Metals \& Materials Society, Pennsylvania, (1999)

15） 国際鉱物資源開発協力協会編：チリ・ペルー調查団報告書, p. 25, (1995)

16) Garcia, C. et al.: Proceedings of the copper 99 international conference, Vol. IV, p. 27, The Minerals, Metals \& Materials Society, Pennsylvania, (1999)

17）日本金属学会編：非鉄金属製錬，p. 231 , 日本金属学会 $(1980)$

18）成田暢彦・匂坂正幸・稲葉 敦 : 資源と素材, Vol. 116, p. 674, (2000)

19) 小林光雄 : State-of-the-Art of LCA activities in Japanese Industry, p. 39, (2000)

20）日本金属学会編：金属製鍊工学, p. 168, 日本金属学会, (1999)

21）金属鉱業事業団 : http://www.mmaj.go.jp

22）資源環境技術総合研究所編：硫黄のバジェット及び技術開発に関寸る調查研究 報告書, p. 59, (1996)

23）安達 毅・匂坂正幸 : 資源 - 素材 '99, A- 京都, p. 25, 資源 - 素材学会, (1999)

24) Castro, S.H. et al.: Proceedings of the copper 99 international conference, Vol. II, p. 297, The Minerals, Metals \& Materials Society, Pennsylvania, (1999) 